\title{
LEGAL ANALYSIS ON THE MANAGEMENT OF SUROBOYO BUS PUBLIC TRANSPORTATION IN SURABAYA CITY
}

\author{
Alam Subuh Fernando \\ Universitas Airlangga \\ J1. Dharmawangsa Dalam Selatan, Airlangga, Surabaya \\ e-mail: alam.subuh.fernando-2018@pasca.unair.ac.id \\ Heru Irianto \\ Universitas Bhayangkara \\ Jl. Ahmad Yani No.14, Ketintang \\ e-mail: heru@ubhara.ac.id \\ Alya Adelina \\ Universitas Airlangga \\ Jl. Dharmawangsa Dalam Selatan, Airlangga, Surabaya \\ e-mail: adelina.alya@yahoo.com \\ Xavier Nugraha \\ Universitas Airlangga \\ Jl. Dharmawangsa Dalam Selatan, Airlangga, Surabaya \\ e-mail: xavier.nugraha-2015@fh.unair.ac.id
}

\begin{abstract}
Abstrak: Di Kota Surabaya, dalam rangka untuk memudahkan mobilisasi terdapat kebijakan terkait dengan kendaraan bermotor umum, yaitu Suroboyo Bus. Sistem sistem pembayaran yang digunakan adalah denganmenggunakan sampah botol plastik dengan tujuan untuk menjaga kebersihan Kota Surabaya. Dalam praktiknya, ternyata Surboyo Bus ini beroperasi dengan plat nomor berwarna merah, padahal di dalam Peratuan Kepala Kepolisian Negara Republik Indonesia No. 5 Tahun 2012 tentang Registrasi dan Identifikasi Kendaraan Bermotor, dijelaskan bahwa kendaraan dengan plat nomor berwarna merah adalah kendaraan milik pemerintah yang notabene tidak boleh memungut pembayaran. Berdasarkan hal tersebut, maka rumusan masalah dalam penelitian ini adalah: 1) Apakah penggunaan plat nomor berwarna kuning pada Suroboyo Bus telah sesuai dengan ketentuan peraturan perundang-undangan? 2) Bentuk pengelolaan seperti apa yang sesuai dalam mengelola kendaraan bermotor umum Surboyo Bus? Penelitian ini merupakan penelitian normatif, dengan mengaji dan menganalisa peraturan perundang-undangan ataupun bahan hukum lain yang berkaitan dengan pengelolaan Suroboyo Bus di Kota Surabaya. Penelitian ini menggunakan pendekatan peraturan perundang-undangan dan pendekatan konseptual. Berdasarkan hasil penelitian ini, ditemukan bahwa 1) Penggunaan plat merah pada kendaraan bermotor umum bertentangan dengan Pasal 39 Peratuan Kepala Kepolisian Negara Republik Indonesia No. 5 Tahun 2012 tentang Registrasi dan Identifikasi Kendaraan Bermotor, dan 2) Pengelolaan Suroboyo Bus sebaiknya beralih dari Dinas Pemerintah Kota Surabaya ke BUMD, karena Pengelolaan dengan sistem BUMD akan menyebabkan pengelolaan manajemen baik manajemen keuangan maupun manajemen organisasinya akan bersifat lebih luas dan tidak terikat pada APBD
\end{abstract}


Kata Kunci: Suroboyo Bus, BUMD, Plat Nomor Berwarna Kuning, Plat Nomor Berwarna Merah

\begin{abstract}
In the city of Surabaya, to facilitate mobilization a public means of transportation exists, namely the Suroboyo Bus. The payment system applied for the bus is by using plastic bottle waste to maintain the Sanitation of the city. In practice, it turns out that Surboyo Bus operates with a red plate number, even though in the Indonesian Police Chief Association No. 5 of 2012 concerning Registration and Identification of Transportations, it is explained that vehicles with red plate numbers are government-owned vehicles which in fact should not collect payments. Based on the stated issue, the problem formulations in this study are: 1) Does the use of yellow plates number on the Suroboyo Bus comply with statutory provisions? 2) What forms of management are appropriate in managing Surboyo Buses public transportation? This research is a normative study, by reviewing and analyzing laws and regulations or other legal materials relating to the management of Suroboyo Bus in Surabaya. This research uses the statutory approach and conceptual approach. Based on the results of this study, it was found that 1) The use of a red plate on public transportation is contrary to Article 39 of the Indonesian Police Chief Regulation No. 5 of 2012 concerning Registration and Identification of Transportations, and 2) Management of Suroboyo Buses should move from the Surabaya City Government Office to become a Province owned business because the management system in province owned business will cause the management of both financial management and organizational management to be broader and not bound to the regional budget.
\end{abstract}

Keywords: Suroboyo Bus, Region owned business, Yellow Plate number, Red Plate Number

\section{INTRODUCTION}

The current rapid globalization has also affected the level of population mobility in cities across the globe. The level of mobility must also be balanced with the existence of transportation, which is a primary need for each individual in carrying out various activities.

Transportation is an important aspect that functions as the pulse of life and economic, social, political, and population mobility to support the developments in

${ }^{1}$ Abdul Kadir, “Transportasi: Peran Dan Dampaknya Dalam Pertumbuhan Ekonomi various sectors of society. ${ }^{1}$ One of the cities in Indonesia which has a high level of movement is Surabaya. The high degree of mobility is the impact of the rapid population growth in the city of Surabaya.

The increasing population in Surabaya is directly proportional to the level of mobility. The high level of community mobility needs to be balanced with the availability of transportation that can accommodate the people in carrying out various activities. The increase in the number of population which is not Nasional," Jurnal Perencanaan Dan Pengembangan Wilayah Wahana Hijau 1, no. 3 (2006): 21. 
insignificant is certainly followed by an increase in the volume of personal transportation, as a result, the potential problems that arise is a traffic jam. One of the cities experiencing severe traffic jam problems in Indonesia is Surabaya, where data released by the Asian Development Bank in the Update of the Asian Development Outlook places Surabaya in the 20th position as the city with the worst traffic jam in Southeast Asia, and in the third position in Indonesia after Bandung and Jakarta. $^{2}$

Surabaya as one of the metropolitan cities in Indonesia requires a mode of public transportation that can overcome the problem of traffic jam. ${ }^{3}$ One step in reducing traffic jam is to optimize public transportation as an alternative to private vehicles in accommodating all forms of mobility. Efforts to optimize public transportation are through the transportation system policy because an efficient transportation system can reduce traffic jam problems and is also able to facilitate regional development and economic growth. ${ }^{4}$ One of the new policies in the transportation system in Surabaya is the existence of public transportation innovation, the Suroboyo Bus. Suroboyo Bus is a public transportation mode with a payment system using a used plastic bottle,,$^{5}$ it means that the people of Surabaya who want to use the transportation service facilities must submit a certain amount of plastic bottle waste to be exchanged for several points that can be used to ride the Suroboyo Bus. ${ }^{6}$

The Suroboyo Bus Innovation is even able to bring Surabaya to be the only city in Indonesia that became the finale of the 2018 Guangzhou International Award because Surabaya is considered to have a good innovation and city development and one on that great innovation is the Suroboyo Bus. ${ }^{7}$

The payment policy of using a used plastic bottle is essentially to use plastic waste productively so that in addition to reducing traffic jam problems, Suroboyo
2 Eduardo Simorangkir, "Daftar Terbaru Kota Termacet di Dunia, Jakarta Urutan Berapa?", https://finance.detik.com/berita-ekonomibisnis/d-4731747/daftar-terbaru-kota-termacet-didunia-jakarta-urutan-berapa, 03 Oktober 2019, dikunjungi pada 23 Maret 2020.

3 Zuhri Muhis and Wahju Herijanto, "Manajemen Lalu Lintas Akibat Trem Di Jalan Raya Darmo Surabaya," Jurnal Teknik ITS 3, no. 1 (2014): 31.

4 Join Hengkeng, "Analisis Peran Retribusi Transportasi Darat Terhadap Perekonomian Di Kabupaten Poso," Katalogis 3, no. 8 (n.d.): 28.

5 Rony Bachtiar Firmansyah, "Inovasi Kebijakan Transportasi Publik: Studi Kasus Program Suroboyo Bus Membayar Dengan Limbah Botol
Plastik" (PhD Thesis, UIN Sunan Ampel Surabaya, 2019), 5.

${ }^{6}$ Humas Surabaya, "Wujudkan Moda Trasnportasi Massal di Surabaya", https://humas.surabaya.go.id/2019/04/12/wujud kan-moda-transportasi-massal-di-surabaya/, $\quad 12$ April 2019, dikunjungi pada 23 Maret 2020.

7 Humas Kota Surabaya, "Wali Kota Risma Paparkan Surabaya Dalam Ajang The Guangzhou International Award 2018", https://humas.surabaya.go.id/2018/12/07/walikota-risma-paparkan-surabaya-dalam-ajang-theguangzhou-international-award-2018/, Desember 2018, dikunjungi 23 Maret 2020. 
Bus is also expected to be an environmentally friendly means of transportation.

Behind the various advantages of the Suroboyo Bus innovation, some things must be further analyzed, where when looking at the motor vehicle number license (TNKB) or generally known as the license plate number of the Suroboyo Bus it turns out to be a red plate number. When referring to the Regulation of the Head of the Indonesian National Police Number 5 of 2012 concerning Registration and Identification of Transportations, wherein article 39 number 3 states that "TNKB (License plate) Color is as follows: b. a yellow background, black writing for general vehicles" As for what is referred to as a public vehicle or Public Transportation as according to Law Number 22 of 2009 concerning Road Traffic is mentioned is a vehicle used for the transportation of goods and / or people with a fee. If we review on Suroboyo Bus, Suroboyo Bus is a public transportation service facility provided by the Surabaya City Government to transport people from one place to another, in other words, this Suroboyo Bus belongs to the Public Transportations (public domain) which should have yellow plate number.
Based on this background, the formulation of the problem in this research is

1) Does the use of yellow plate numbers on the Suroboyo Bus comply with statutory provisions?

2) What form of management is appropriate to manage the Suroboyo Bus public transportation?

\section{METHOD}

This research is a legal research, that puts the law as a norm system building, which consists of principles, norms, rules of legislation, court decisions, agreements and doctrines/teachings. ${ }^{8}$ This normative research is carried out by studying and analyzing laws and regulations or other legal materials related to the topic of discussion. The approach used in this study is the statutory approach, the conceptual approach, and the comparative approach

The legislative approach is conducted by examining all laws and regulations relating to the legal issues in question, so that legis ratios, ontological basis and philosophical basis of regulations relating to the Surboyo Bus transportation policies. ${ }^{9}$ Regulations regarding the Suroboyo Bus transportation policy include Law Number 22 of 2009 concerning Road Traffic, Mayor Regulation
8 Depri Liber Sonata, "Metode Penelitian Hukum Normatif Dan Empiris: Karakteristik Khas Dari Metode Meneliti Hukum," Fiat Justisia Jurnal Ilmu Hukum 8, no. 1 (2017): 15-35.
9 Zayanti Mandasari, "Politik Hukum Pengaturan Masyarakat Hukum Adat (Studi Putusan Mahkamah Konstitusi)," Jurnal Hukum IUS QULA IUSTUM 21, no. 2 (2014): 231. 
Number 67 of 2018 concerning Contribution of Waste in the Use of Surabaya Bus Services, and Regulation of the Head of the Indonesian National Police Number 5 of 2012 concerning Motorized Vehicle Registration and Identification.

A conceptual approach is an approach that moves from the views and doctrines and develops in the science of law. ${ }^{10}$

This approach is carried out with an understanding of the concepts put forward by experts contained in various kinds of literature, especially relating to public transportation policy systems, ${ }^{11}$ such as by conducting studies and analysis of the problem formulation through the use of theories and developing doctrines namely theories about the transportation system, public policy, and various other theories relating to the application of the Suroboyo Bus policy. A comparative approach is an approach by conducting a comparative study of law, ${ }^{12}$ wherein this study will compare the means of public transportation Suroboyo Bus with several other means of public transportation found in various cities in Indonesia.

\section{RESULT AND DISCUSSION}

\section{Legitimate Use of Yellow Plate Number} on Suroboyo Bus

According to Morlk, transportation, is defined as the activity of moving or lifting something from one place to another. ${ }^{13}$ Furthermore, Steebrink defines transportation as the movement of people or goods using tools or vehicles to and from geographically separated places. ${ }^{14}$ Thus, it can be concluded that transportation is essentially a facility used by the community to move from one place to another to achieve certain goals. Transportation in this case certainly requires basic services or facilities and equipment needed by the community as the implementation of the functions of an area. ${ }^{15}$

In providing transportation services in Surabaya City, the Surabaya City Government has made a new policy. The policy is essentially a political decision taken

\footnotetext{
10 Zulfadli Barus, “Analisis Filosofis Tentang Peta Konseptual Penelitian Hukum Normatif Dan Penelitian Hukum Sosiologis," Jurnal Dinamika Hukum 13, no. 2 (2013): 313.

11 Sayyidatul Insiyah, Xavier Nugraha, and Shevierra Danmadiyah, "Pemilihan Kepala Daerah Oleh Dewan Perwakilan Rakyat Daerah: Sebuah Komparasi Dengan Pemilihan Secara Langsung Oleh Rakyat," Supremasi Hukum: Jurnal Penelitian Hukum 28, no. 2 (2019): 169.

12 Peter Mahmud Marzuki, Penelitian Hukum (Jakarta: Kencana, 2005), 172.

13 M. Abi Berkah Nadi, Aleksander Purba, And Ahmad Zakaria, "Analisis Pemilihan Moda Transportasi Rute Tanjung Karang-Bandara Radin
}

Inten Ii Dengan Stated Preference, Uji Crame'sv Dan Uji Chi-Square," 2018, 91.

14 Mahdi Zargayouna, "Multi-Agent Approaches For Dynamic Transportation Problems" (Phd Thesis, Université Paris Dauphine, 2019). See Also, Berkah Nadi, Purba, And Zakaria, "Analisis Pemilihan Moda Transportasi Rute Tanjung Karang-Bandara Radin Inten Ii Dengan Stated Preference, Uji Crame'sv Dan Uji Chi-Square."

15 Awing Asmawi, Diah Fatma Sjoraida, and Rully Khairul Anwar, "Masalah Dan Dinamika Implementasi Kebijakan Publik Tentang Transportasi (Kajian Di Kota Tasikmalaya, Jawa Barat)," CosmoGov: Jurnal Ilmu Pemerintahan 3, no. 2 (2017): 207. 
by the government as part of the government's attitude to solve a public problem, ${ }^{16}$ where the public problem referred to in this case is the traffic jam and traffic density of the city of Surabaya. The new policy is in the form of procuring a new transportation mode called the Suroboyo Bus.

The Suroboyo Bus which was officially launched on April 7, 2018, at the Siola building is a form of innovation from the city government of Surabaya.

It is said to be an innovation because the policy made by the Surabaya City Government in providing transportation service facilities has a novelty when compared to other public transportation, namely the Surboyo Bus transportation payment system does not use money but uses used plastic bottle waste exchanged with points as tickets to be exchanged with the Surboyo Bus facility services.

The legal shield for the enactment of Surboyo Bus is Surabaya Mayor Regulation No. 67 of 2018 concerning Contribution of Waste in the Use of Surboyo Bus Services, wherein the considerations it is stated that as one of the efforts to reduce the impact of plastic waste in the area, the Regional
Government contributes to plastic waste to be exchanged with Surboyo Bus services.

The consideration was then realized with the requirement that prospective Surboyo Bus passengers must submit the waste with some terms applied: a) three large used plastic bottles (capacity> $1000 \mathrm{~mL}$ ), b) five used medium-sized plastic bottles (capacity up to $1000 \mathrm{~mL}$ ), or c) ten used plastic water cups. The waste to be exchanged into a ticket must be submitted to the Officials either in the terminal, bus stops, or the Officials on duty at Surboyo Bus. The waste will then be collected every day and then exchanged at the garbage exchange. The payment system using plastic waste is the only policy in Indonesia considering that when comparing with mass transportation modes found in various other cities in Indonesia, the payment system is in the form of electronic cards (e-ticketing).

One of the public transportation similar to Surboyo Bus is the Trans Jakarta Bus. When compared to the Trans Jakarta Bus which has already operated in Jakarta since 2004 , the payment system uses an electronic card instead of cash with a tariff of Rp. 2,000, - (05.00-07.00 WIB), Rp.3,500 (07.00 -24.00 WIB), and Rp. 3,500, - (24.00-05.00 WIB). ${ }^{17}$

\footnotetext{
${ }^{16}$ Dian Fitriani Afifah and Neneng Yani Yuningsih, “Analisis Kebijakan Pemerintah Tentang Pencegahan Dan Penanganan Korban Perdagangan (Trafficking) Perempuan Dan Anak Di Kabupaten Cianjur," Jurnal Ilmu Pemerintahan IS SN 2442 (2016) 335.
}

\footnotetext{
${ }^{17}$ https://www.transjakarta.co.id/produk-danlayanan/info-tiket/, dikunjungi pada 24 Maret 2020.
} 
In addition to Trans Jakarta, there is also Trans Semarang which also sets a tariff of Rp. 3,500. The comparison shows that Surboyo Bus is indeed much affordable by people from all groups considering that the Surabaya City Government does not set a penny but only with plastic bottle waste in the amount as per regulation No. 67 of 2018.

No matter how Surboyo Bus is presented as a solution to overcome traffic jams while reducing the impact of plastic waste in the city of Surabaya, some things must be considered. As a means of transportation that functions to transport people from one area to another, therefore Surboyo Bus is included in the classification of Public Transportation, under the provisions of Article 1 number 10 of Law No. 22 of 2009 concerning Road Traffic (Traffic Act) which confirms that "Public Transportations are any vehicles used for the transportation of goods and / or people with a fee.

Further provisions as referred to in Article 158 paragraph (1) state that "the Government guarantees the availability of road-based mass transportation to meet the transportation needs of people with Public Transportations in urban areas." These provisions further emphasize that the Surboyo Bus provided by the Surabaya City Government is classified as public transportation.
Every transportation basically must be registered to carry out administrative orders. Further provisions regarding the registration of public transportation shall be regulated in the Head of the Indonesian National Police Chief. Regulation no. 5 of 2012 concerning Registration and Identification of Transportations (hereinafter referred to as Perkap No. 5 of 2012). Perkap No. 5 of 2012 confirms that one form of registration and identification of transportation is the issuance of motor vehicle license number (TNKB) or commonly known as license plates. Concerning plate numbers, each type of vehicle has a different color plate classification, wherein in Article 39 paragraph (3) the regulation a quo states that "TNKB (license plate) Color is as follows: a. black, with white writing for individual vehicles and rented vehicles; $b$. yellow base plate, with black writing for public transportation. c. red, white writing for government transportation; d. white basis, BLU (Public Service Agency)e writing for Diplomatic Corps transportation of foreign countries; and green base, black writing for free trade zone transportation which gets import duty exemption facilities and based on the Minister of Finance Regulation, that the vehicle may not be operated/transferred to other parts of Indonesia. " 
Pulling line from the aforementioned provisions, it can be understood that every transportation that has the function of transporting people for a fee is public transportation, where public transportations must have a yellow license plate. Reflecting on Surboyo Bus, the use of license plates on Suroboyo Bus still causes debate.

In its implementation, the license plate number installed on the Surboyo Bus is a red plate. The provisions of the red plate numbers are essential for government official vehicles, namely vehicles used to assist the transportation process within government agencies so that government performance can run well. ${ }^{18}$ On the other hand, Surboyo Bus functions as public transportation that transport people from one area to another in the city of Surabaya this is increasingly emphasized in the provisions of Article 1 number 14 of Mayor regulation of Surabaya No. 67 of 2018 which defines the Suraboyo Bus as a bus owned by the Surabaya City Government which is used as public transportation. ${ }^{19}$ The assertion that Suroboyo Bus is public transportation should have implications for the installation of yellow plate numbers.
However, to this day, the reality is that Surboyo Bus still uses a red plate number as the vehicle's identity.

One reason for using the red plate on the Surboyo Bus as according to the Head of the Transportation Office, Irvan Wahyudrajad, is that in principle the Surboyo Bus operation is free, but the Surabaya City Government provides privileges for people who collect plastic bottle waste to get free tickets equal to the amount of waste collected. ${ }^{20}$

Even though the public is not charged at all to be able to enjoy Surboyo Bus, plastic bottles from the contribution of using the Surboyo Bus service can be sold by the Surabaya City Green Cleaning and Open Space Office so that in the end the collection of plastic bottle waste from using Surboyo Bus services can generate money. This is proven by the auction of the collection of plastic bottle waste. As stipulated in Article 7 of Mayor Regulation No. 67 of 2018 where waste generated from the use of the Surboyo Bus service is determined as regional property, the auction of plastic waste is carried out by the
18 Ahmad Rifai, "Sistem Informasi Pemantauan Kendaraan Dinas Unsri Menggunakan Teknologi GPS," Jurnal Sistem Informasi 5, no. 2 (March 2013): 603.

19 In Article 1 number 10 of Law 22/2009 the phrase used is public motorized vehicles, while in Article 1 number 14 Perwali 67/2018 the phrase used is public transportation. This seems to have a different meaning, even though they both designate the same mode of transportation.

20 Alief Sambogo, "Kadishub Ngotot Surabaya Bus Pakai Plat Merah Bukan Pelanggaran",https://www.ngopibareng.id/timelin e/irvan-ngotot-tak-masalah-surabaya-bus-platmerah-1751152, 06 Januari 2020, dikunjungi pada 25 Maret 2020. 
Directorate General of State Assets (DJKN). ${ }^{21}$

Since the beginning of the operation, from 2018 to January 2019, the collection of plastic bottle waste from the use of the Surboyo Bus service has reached 39 tons which are accommodated in 2000 garbage banks. 39-ton plastic bottle waste was then auctioned in June 2019 by the DJKN and won by a plastic waste management company into plastic pellets namely PT. Langgeng Jaya Plastindo with the auction result of Rp. 150 million. ${ }^{22}$ The results of these auctions are included in the Surabaya City Revenue and Expenditure Budget (APBD) through Local Revenue. ${ }^{23}$ The auction showed that in the end, plastic bottle waste from the use of the Surboyo Bus service was able to bring benefits to the City of Surabaya government because these benefits could be spent on regional interests.

Thus, even though the Surabaya City government does not set a tariff rate for the community and only requires several plastic bottle waste to be able to enjoy the Surboyo Bus service facility, the final result of the plastic bottles still has value.
The next reason related to the use of the red plate on the Surboyo Bus as according to the Mayor of Surabaya, Tri Trismaharini, is that the purchase of the Surboyo Bus uses the Surabaya City Government's APBD money so that as an asset of the City Government the Surboyo Bus plate number is red. ${ }^{24}$

\section{The Appropriate Managing Institution for Surboyo Bus Public Transportation}

Since license plates in red may not collect fees from the public, an alternative payment system is through plastic bottle waste. To further analyze the management of Surboyo Bus, in Mayor regulation No. 67 of 2018 which is the legal basis of the Surobyo Bus policy, it can be seen that the management of Surboyo Bus is carried out directly by the Surabaya City Government through the Surabaya City Green Cleaning and Open Space Office and the Transportation Office. When comparing with management with several other mass transportation such as the Trans Semarang Bus, the management of the Trans Semarang Bus as per Semarang Mayor Regulation No. 1 of 2017 concerning the Pattern of Governance
21 Dadang Kurnia, "Sampah Botol Plastik Suroboyo Bus Laku Terjual Rp. 150 Juta", https://www.republika.co.id/berita/nasional/daer ah/19/06/12/pszsgh383-sampah-botol-plastiksuroboyo-bus-laku-terjual-rp-150-juta, 13 Juni 2019, dikunjungi pada 25 Maret 2020.

22 Abdul Hakim, "Surabaya Lelang Hasil Sampah Botol Plastik Hasil Penukaran TiketBus",https://www.antaranews.com/berita/9 $12162 /$ surabaya-lelang-sampah-botol-plastik-hasil- penukaran-tiket-bus, 13 Juni 2019, dikunjungi pada 25 Maret 2020.

23 Ibid.

24 Zumrotul Abidin, "Risma Ungkap Alasan Tarif Suroboyo Bus Dibayar Sampah Plastik",https://www.suarasurabaya.net/kelanakot a/2018/Risma-Ungkap-Alasan-Tarif-SuroboyoBus-Dibayar-Sampah-Plastik/, 7 Maret 2018, dikunjungi pada 25 Maret 2020. 
of the Public Service Unit of the Trans Semarang Regional Technical Implementation Unit is managed by the Public Service Agency of the Implementing Unit of Trans Semarang.

As for what is meant by Public Service Agency (BLU) as referred to in Article 1 number 1 of Government Regulation No. 23 of 2005 concerning Financial Management of Public Service Bodies as amended by Government Regulation No. 74 of 2012, is an agency within the government that was formed to provide services to the community in the form of the supply of goods and/or services sold without prioritizing profit-seeking and in carrying out its activities based on the principles of efficiency and productivity.

One of the bases for the formation of the BLU (Public Service Agency) is that in the government environment there are many units of activity that have the potential to be managed with a more effective and efficient business model, so the administrative and regulative functions of the government have expanded so that in 2005, through Government Regulation No. 23 of 2005 concerning Financial Services Management Public Service Agency, the government provides space for performance-based budgeting, namely BLU(Public Service Agency). ${ }^{25}$

The BLU (Public Service Agency is formed by government work units that carry out public service operational tasks to distinguish them from government functions as regulators and policymakers, where the agentification of activities that do not have to be carried out by pure bureaucratic institutions, but are carried out by agencies that are managed in business style so services to the community become more effective and efficient. ${ }^{26}$

Aside from being in the form of BLU (Public Service Agency), public services can also be provided by two other forms of institutions, namely by ordinary work units, which are ordinary bureaucratic institutions with limited or no degree of economy and independence, and state-owned businesses as a true public/state institution completely autonomous in managing every resource and decision making. ${ }^{27}$

Table 1. Comparison of General WorkForce, BLU (Public Service Agency), and State/Region owned business

\begin{tabular}{|c|c|c|}
\hline $\begin{array}{c}\text { General } \\
\text { Work Force }\end{array}$ & $\begin{array}{c}\text { Public } \\
\text { Service } \\
\text { Agency }\end{array}$ & $\begin{array}{c}\text { Sate / } \\
\text { Government } \\
\text { Owned } \\
\text { Business }\end{array}$ \\
\hline $\begin{array}{c}\text { The services } \\
\text { provided are } \\
\text { not intended } \\
\text { for profit. }\end{array}$ & $\begin{array}{c}\text { BEU } \\
\text { SERVICE } \\
\text { AGENCY) } \\
\text { may make a }\end{array}$ & $\begin{array}{c}\text { The main } \\
\text { motive of the } \\
\text { activity is } \\
\text { profit-seeking. }\end{array}$ \\
\hline
\end{tabular}

27 Henny Juliani, "Eksistensi Badan Layanan Umum Sebagai Penyelenggara Pelayanan Publik," Administrative Law \& Governance Journal 1, no. 2 (2018): 149-164.
25 Fadhilah Mathar, Pemanfaatan Teknologi Dalam Menunjang Implementasi Good Govermamce Di Badan Layanan Umum Pemerintah, Jurnal Teknik Informatika, Vol 5, No 1, 2012, h 2.

${ }^{26}$ Ibid. 


\begin{tabular}{|c|c|c|}
\hline & $\begin{array}{l}\text { profit } \\
\text { through a set } \\
\text { tariff, but } \\
\text { profit is not } \\
\text { the main } \\
\text { goal. }\end{array}$ & \\
\hline $\begin{array}{l}\text { The financial } \\
\text { management } \\
\text { system is not } \\
\text { autonomous } \\
\text { but following } \\
\text { the APBN } \\
\text { mechanism. }\end{array}$ & $\begin{array}{l}\text { The financial } \\
\text { management } \\
\text { system is } \\
\text { semi- } \\
\text { autonomous, } \\
\text { making it } \\
\text { more } \\
\text { flexible. }\end{array}$ & $\begin{array}{c}\text { The } \\
\text { managerial } \\
\text { financial } \\
\text { management } \\
\text { system is } \\
\text { broad, with a } \\
\text { pure business } \\
\text { financial } \\
\text { management } \\
\text { system. }\end{array}$ \\
\hline $\begin{array}{l}\text { Revenues } \\
\text { derived from } \\
\text { the results of } \\
\text { public } \\
\text { services are } \\
\text { fully } \\
\text { included in } \\
\text { the Non-Tax } \\
\text { State } \\
\text { Revenue } \\
\text { (PNBP). }\end{array}$ & $\begin{array}{c}\text { Revenues } \\
\text { derived from } \\
\text { the results of } \\
\text { public } \\
\text { services are } \\
\text { fully } \\
\text { included in } \\
\text { the PNBP }\end{array}$ & $\begin{array}{l}\text { Revenues } \\
\text { earned from } \\
\text { business } \\
\text { activities are } \\
\text { not fully } \\
\text { included in } \\
\text { PNBP. }\end{array}$ \\
\hline $\begin{array}{c}\text { Not subject } \\
\text { to tax. }\end{array}$ & $\begin{array}{c}\text { Is subject to } \\
\text { tax. }\end{array}$ & $\begin{array}{l}\text { Also subject to } \\
\text { tax. }\end{array}$ \\
\hline $\begin{array}{l}\text { The assets } \\
\text { are not } \\
\text { separate } \\
\text { from state } \\
\text { assets. }\end{array}$ & $\begin{array}{l}\text { The Assets } \\
\text { are not } \\
\text { separate } \\
\text { from state } \\
\text { assets. }\end{array}$ & $\begin{array}{l}\text { The assets are } \\
\text { separate from } \\
\text { state assets. }\end{array}$ \\
\hline $\begin{array}{l}\text { It is a general } \\
\text { bureaucratic } \\
\text { institution. }\end{array}$ & & \\
\hline
\end{tabular}

Referring to the comparison table 1., if it is associated with Surboyo Bus, where the management of Surboyo Bus is carried out directly by the state bureaucratic institution, namely by the Transportation Office in cooperation with the Surabaya City Green Cleaning and Open Space Office. Besides, considering that Surboyo Bus purchases are made using the total APBD, then Surboyo Bus is not intended to generate benefits. As proof, the City Government of Surabaya does not set tariffs for people who want to enjoy the Surboyo Bus service, but only requires a certain amount of plastic bottle garbage. Besides, as per the provisions of Mayor regulation No. 67 of 2018 the waste generated from the contribution of the use of the Surabaya Bus service is determined as Regional Property so that it becomes a single entity that is not separate from the country's wealth.

Based on some of these characteristics, it can be concluded that the management of Surboyo Bus is carried out by ordinary work units, namely under the city government bureaucracy directly in this case the Department of Transportation and the Department of Sanitation and Green Open Space of the City of Surabaya. According to several things, it is a logical consequence if the license plate on the Surboyo Bus is red, considering that the Surabaya City Government does not seek profit through setting tariffs on the use of the Surboyo Bus service, although in the end, the management of Surboyo Bus can also benefit through the results of the auction is included in the regional income.

Comparing with other public motor vehicle modes, for example, the Trans Semarang Bus, it can be seen that the management of the Trans Semarang Bus uses a management system through the Public Service Agency (BLU). Even though the activity does not prioritize profit, it refers to the provisions of Article 9 PP No. 
74 of 2012 concerning Amendment to Government Regulation Number 23 of 2005 concerning Financial Management of Public Service Agencies, BLU may collect fees to the public as compensation for goods/services provided where the compensation provided is determined in the form of tariffs.Furthermore, in the provision of Article 1 number 10 Semarang Mayor Regulation No. In 2017, the technical guidelines for Financial Management and Accounting of the Trans Semarang Regional Technical Implementation Unit as a Public Service Agency stated that the financial management pattern provides flexibility in the form of flexibility to implement sound business practices to improve services to the community. This then underlies the establishment of tariffs for people who wants to ride the Trans Semarang Bus facilities, which is Rp. 3,500, -, so that is a logical consequence when the plate numbers used on the Trans Jakarta Bus are yellow.

Similar modes of transportation for rapid transit are also found in the city of Jakarta, as it is known as the Trans Jakarta Bus. Similar to the Trans Semarang Bus, the plate numbers used by Trans Jakarta are also

${ }^{28}$ Alsadad Rudi, "Jokowi Resmi ubah Transjakarta Jadi BUMD", https://megapolitan.kompas.com/read/2014/03/ 27/1021311/Jokowi.Resmi.Ubah.Transjakarta.Jadi yellow, it's just that between the two there are differences in the form of management.

Unlike the Trans Semarang Bus, the Trans Jakarta Bus management is carried out in the form of Region owned business namely PT. Transportation in Jakarta, after previously the management of Trans Jakarta was carried out by the Trans Jakarta BLU (Public Service Agency) under the DKI Jakarta Provincial Transportation Agency, which was stipulated through DKI Jakarta Governor Regulation No. 48 of 2006 concerning the Establishment, Organization and Administration of the Trans Jakarta Busway Public Service Agency.

The change in the management system from BLU (Public Service Agency) to Region owned Business which occurred on March 27, 2014, has consequences for share ownership where the ownership of the DKI Jakarta Provincial Government in Trans Jakarta Buses is $99 \%$, while 1 percent is owned by PT. Jakarta Propertindo Budi Karya Samadi as a shareholder company in addition to the DKI Jakarta Provincial Government. ${ }^{28}$

One form of the region or state-owned business found in the regions is in the form of a joined company where one of its main objectives is to seek profits. ${ }^{29}$ Likewise with

$\underline{\text { BUMD }}, 27$ Maret 2014, dikunjungi pada 25 Maret 2020.

${ }^{29}$ Ambar Budhisulistyawati, Yudho Taruno Muryanto, and Anjar Sri CN, "Strategi Pengelolaan Badan Usaha Milik Daerah (BUMD) Persero Untuk 
Trans Jakarta Bus where the purpose of changing the form of management of Trans Jakarta from BLU (Public Service Agency) to state-owned business is in the context of increasing efficiency and effectiveness. The change in form of management is based on the reason that when Trans Jakarta takes the form of BLU it is still very much bound to the bureaucratic process of the DKI Jakarta Provincial Government which takes a long time, for example repairing damaged facilities must go through processes such as data collection of damages, auction of repair parties, and signing of contracts with the contractor where the process takes up to one month, even if the repair of the facility is handled by the company can be completed within three days. Besides, the form of BLU (Public Service Agency) makes Trans Jakarta operations highly dependent on the regional budget, so that if the budget for repairs for Trans Jakarta is not available in the budget plan, the process of repairing the Trans Jakarta facility will be hampered. ${ }^{30}$

Even though there was a change in the form of management from BLU (Public Service Agency) to state-owned business, the tariff applied to enjoy the services of the Trans Jakarta facility did not change, that is, it still ranged from Rp. 2,000 up to Rp.

Mewujudkan Prinsip Tata Kelola Perusahaan Yang Baik," Privat Law 3, no. 2 (2016): 57.

${ }^{30}$ Wahyu Praditya Purnomo, "BLU Trans Jakarta Sebaiknya Diubah Jadi BUMD", https://inilah.com/news/1874341/blu-
3,500, according to operating hours. Through changing the form of management it is increasingly emphasized that the purpose of Trans Jakarta is in the context of seeking profit, in addition to being a facilitator in providing public motorized mode services. Some of these reasons make the use of yellow plate numbers for Trans Jakarta vehicles in operation.

To Improve management of Surboyo Bus, it is necessary to change the form of management of the Surboyo Bus. The solutions that can be offered are; 1) To change the form of management of Surboyo Bus which is still managed directly by the government bureaucratic agency, in this case, the Office of Sanitation and Green Open Space and the Office of Transportation to a form of Region Owned Business. Management with the Region Owned Business system will provide more advantages compared to management by the BLU or by bureaucratic institutions / ordinary work units because if management is carried out by the business entity, the nature of management both financial management and organizational management will be broader and not bound to the regional budget. This will certainly provide more flexible room for the regional owned business to be able to provide

transjakarta-sebaiknya-diubah-jadi-bumd, 20 Juni 2012, dikunjungi pada 25 Maret 2020. 
maximum public services for the community because the region owned business is not bound by the government bureaucratic process. The change in the form of management of region owned business will certainly not change the ownership of the Surabaya City Government to Surboyo Bus, because later the Surabaya City Government can dominate the ownership of shares as carried out by the DKI Jakarta Provincial Government over the ownership of Trans Jakarta shares in PT. Jakarta transportation, which is $99 \%$.

The second step that can be taken after changing the form of management to BUMD is by; 2) make changes to the Suroboyo Bus plate, which is from a red plate to a yellow plate. The change is very logical considering Suroboyo Bus is not an official vehicle but is public transportation that functions to transport people to move from one area to another in the city of Surabaya. The change in color of the plate number to yellow will not change the original intent of the formation of the Surboyo Bus, which is to reduce the impact of plastic waste in the city of Surabaya, because the results of the collection of plastic waste, in the end, can also still generate money, namely through the auction of the collection of results plastic waste so that it is still able to provide benefits to region owned business.

Changing the color of the red plate to yellow plates will also make the payment system more flexible, considering that one of the reasons for not charging fees other than to reduce the impact of plastic waste is because the Suroboyo Bus plate number is still red. Through the change of the plate number color, it certainly opens the way for the government to be able to collect fees from people who want to enjoy the Suroboyo Bus facilities as other public transportation so that the government can collect fees for the use of the facility's services, for example by applying the number of payment tickets as in another rapid transit bus which is around $\mathrm{Rp}$. 3,500, - Through these two payment system choices, it will create even greater benefits because the public is given two choices when using the Surboyo Bus service, which is whether to pay with money or continue to choose the method of payment in exchange for plastic bottle. After all, salus populi suprema lex, where people's welfare is the highest law. ${ }^{31}$

\section{CONCLUSION}

Analyzing the results of comparisons between Trans Semarang Bus, Trans Jakarta Bus, and Surboyo Bus, it can be seen that

Kompetisi Elektoral, Jurnal Ilmiah Ilmu Pemerintahan, Vol 4, No 1, September 2019, h 1.
31 Hendra Try Ardianto, Uang dan Partai Politik : Urgensi Mengatur Keuangan Parpol dan Kandidat dalam 
the reason for using the red plate numbers on Surboyo Bus is because the form of management is still managed directly by the Surabaya City Government through the Sanitation Office and Green Open Space and Surabaya City Transportation Office. On the other hand, Surboyo Bus is a public transportation, so that if Surboyo Bus continues to transport people using red plate numbers, this is not under statutory provisions.

\section{REFERENCES}

Afifah, Dian Fitriani, and Neneng Yani Yuningsih. "Analisis Kebijakan Pemerintah Tentang Pencegahan Dan Penanganan Korban Perdagangan (Trafficking) Perempuan Dan Anak Di Kabupaten Cianjur." Jurnal Ilmu Pemerintahan ISSN 2442 (2016): 5958.

Asmawi, Awing, Diah Fatma Sjoraida, and Rully Khairul Anwar. "Masalah Dan Dinamika Implementasi Kebijakan Publik Tentang Transportasi (Kajian Di Kota Tasikmalaya, Jawa Barat)." CosmoGov: Jurnal Ilmu Pemerintahan 3, no. 2 (2017): 205218.

Barus, Zulfadli. "Analisis Filosofis Tentang Peta Konseptual Penelitian Hukum Normatif Dan Penelitian Hukum Sosiologis." Jurnal Dinamika Hukum 13, no. 2 (2013): 307-318.

Berkah Nadi, M. Abi, Aleksander Purba, and Ahmad Zakaria. "Analisis Pemilihan Moda Transportasi Rute Tanjung Karang-Bandara Radin Inten Ii Dengan Stated Preference, Uji Crame'sv Dan Uji Chi-Square," 2018.

Budhisulistyawati, Ambar, Yudho Taruno Muryanto, and Anjar Sri CN.
"Strategi Pengelolaan Badan Usaha Milik Daerah (BUMD) Persero Untuk Mewujudkan Prinsip Tata Kelola Perusahaan Yang Baik." Privat Law 3, no. 2 (2016): 164361.

Firmansyah, Rony Bachtiar. "Inovasi Kebijakan Transportasi Publik: Studi Kasus Program Suroboyo Bus Membayar Dengan Limbah Botol Plastik." PhD Thesis, UIN Sunan Ampel Surabaya, 2019.

Hengkeng, Join. "Analisis Peran Retribusi Transportasi Darat Terhadap Perekonomian Di Kabupaten Poso." Katalogis 3, no. 8 (n.d.).

Insiyah, Sayyidatul, Xavier Nugraha, and Shevierra Danmadiyah. "Pemilihan Kepala Daerah Oleh Dewan Perwakilan Rakyat Daerah: Sebuah Komparasi Dengan Pemilihan Secara Langsung Oleh Rakyat." Supremasi Hukum: Jurnal Penelitian Hukum 28, no. 2 (2019): 164-187.

Juliani, Henny. "Eksistensi Badan Layanan Umum Sebagai Penyelenggara Pelayanan Publik." Administrative Law \& Governance Journal 1, no. 2 (2018): 149-164.

Kadir, Abdul. "Transportasi: Peran Dan Dampaknya Dalam Pertumbuhan Ekonomi Nasional." Jurnal Perencanaan Dan Pengembangan Wilayah Wahana Hijau 1, no. 3 (2006): 84-131.

Mandasari, Zayanti. "Politik Hukum Pengaturan Masyarakat Hukum Adat (Studi Putusan Mahkamah Konstitusi)." Jurnal Hukum Ius Quia Iustum 21, no. 2 (2014): 227-250.

Marzuki, Peter Mahmud. Penelitian Hukum. Jakarta: Kencana, 2005.

Muhis, Zuhri, and Wahju Herijanto. "Manajemen Lalu Lintas Akibat Trem Di Jalan Raya Darmo Surabaya." Jurnal Teknik ITS 3, no. 1 (2014): E37-E42.

Rifai, Ahmad. "Sistem Informasi Pemantauan Kendaraan Dinas Unsri Menggunakan Teknologi GPS." Jurnal Sistem Informasi 5, no. 2 (March 2013). 
Sonata, Depri Liber. "Metode Penelitian Hukum Normatif Dan Empiris: Karakteristik Khas Dari Metode Meneliti Hukum." Fiat Justisia Jurnal Ilmu Hukum 8, no. 1 (2017): 15-35.

Zargayouna, Mahdi. "Multi-Agent Approaches for Dynamic Transportation Problems." $\mathrm{PhD}$ Thesis, Université Paris Dauphine, 2019.

\section{RULES OF LAW}

Undang-Undang Dasar Negara Republik Indonesia Tahun 1945

Undang-Undang No. 22 Tahun 2009 tentang Lalu Lintas dan Angkutan Jalan. Lembaran Negara RI Tahun 2009 Nomor 96, Tambahan Lembaran Negara Nomor 5025. Sekretariat Negara. Jakarta.

Peraturan Wali Kota Nomor 67 Tahun 2018 tentang Kontribusi Sampah dalam Penggunaan Layanan Bus Surabaya. Berita Daerah Kota Surabaya Tahun 2018 Nomor 68, Sekretaris Daerah. Surabaya.

Peraturan Kepala Kepolisian Negara Republik Indonesia Nomor 5 Tahun 2012 tentang Registrasi dan Identifikasi Kendaraan Bermotor. Berita Negara Republik Indonesia Tahun 2012 Nomor, Menteri Hukum dan Ham Republik Indonesia. Jakarta.

\section{WEBSITE}

Abdul Hakim, "Surabaya Lelang Hasil Sampah Botol Plastik Hasil Penukaran Tiket Bus", https://www.antaranews.com/be rita/912162/surabaya-lelangsampah-botol-plastik-hasilpenukaran-tiket-bus, 13 Juni 2019, dikunjungi pada 25 Maret 2020.

Alief Sambogo "Kadishub Ngotot Surabaya Bus Pakai Plat Merah Bukan Pelanggaran", https://www.ngopibareng.id/tim eline/irvan-ngotot-tak-masalahsurabaya-bus-plat-merah-
1751152, 06 Januari 2020, dikunjungi pada 25 Maret 2020.

Alsadad Rudi, "Jokowi Resmi ubah Transjakarta Jadi BUMD", https://megapolitan.kompas.com $\angle \mathrm{read} / 2014 / 03 / 27 / 1021311 / \mathrm{Jok}$ owi.Resmi.Ubah.Transjakarta.Jadi .BUMD, 27 Maret 2014, dikunjungi pada 25 Maret 2020.

Dadang Kurnia, "Sampah Botol Plastik Suroboyo Bus Laku Terjual Rp. 150 Juta", https://www.republika.co.id/beri ta/nasional/daerah/19/06/12/ps zsgh383-sampah-botol-plastiksuroboyo-bus-laku-terjual-rp-150juta, 13 Juni 2019, dikunjungi pada 25 Maret 2020.

Eduardo Simorangkir, "Daftar Terbaru Kota Termacet di Dunia, Jakarta Urutan Berapa?", https://finance.detik.com/beritaekonomi-bisnis/d- Humas Surabaya, "Wujudkan Moda Trasnportasi Massal di Surabaya", https://humas.surabaya.go.id/20 19/04/12/wujudkan-modatransportasi-massal-di-surabaya/, 12 April 2019, dikunjungi pada 23 Maret 2020.

Humas Kota Surabaya, "Wali Kota Risma Paparkan Surabaya Dalam Ajang The Guangzhou International Award 2018", https://humas.surabaya.go.id/20 18/12/07/wali-kota-rismapaparkan-surabaya-dalam-ajangthe-guangzhou-internationalaward-2018/, 7 Desember 2018, dikunjungi 23 Maret 2020.

Wahyu Praditya Purnomo, "BLU Trans Jakarta Sebaiknya Diubah Jadi BUMD", https://inilah.com/news/187434 1/blu-transjakarta-sebaiknyadiubah-jadi-bumd, 20 Juni 2012, dikunjungi pada 25 Maret 2020.

Zumrotul Abidin, "Risma Ungkap Alasan Tarif Suroboyo Bus Dibayar 
Sampah

Plastik",

https://www.suarasurabaya.net/k elanakota/2018/Risma-Ungkap-

Alasan-Tarif-Suroboyo-Bus-
Dibayar-Sampah-Plastik/, 7 Maret 2018, dikunjungi pada 25 Maret 2020 . 